\title{
Chlamydia trachomatis major outer membrane protein epitopes expressed as fusions with LamB in an attenuated aro $A$ strain of Salmonella typhimurium; their application as potential immunogens
}

\author{
L. J. Hayes, ${ }^{*}$ J. W. Conlan, J. S. Everson, M. E. Ward and I. N. Clarke \\ Department of Microbiology, University of Southampton Medical School, Southampton General Hospital, Tremona Road, \\ Southampton SO9 $4 X Y$
}

(Received 5 November 1990; revised 19 February 1991; accepted 2 April 1991)

\begin{abstract}
The major outer-membrane protein (MOMP) of Chlamydia trachomatis is the focus of attention for chlamydial vaccine design, particularly those serovar- and subspecies-specific epitopes which provoke neutralizing immune responses. Selected surface-exposed B-cell epitopes of MOMP, incorporating B-subspecies specificities, were expressed as fusions with LamB, an inducible outer-membrane transport protein of Escherichia coli. These recombinant chlamydial-LamB proteins were correctly transported to the outer membrane of both $E$. coli and an aro $A$ mutant of Salmonella typhimurium. The immunogenicity of the constructs was investigated in a mouse model of chlamydial salpingitis. After oral immunization, recombinant $S$. typhimurium were recovered from the livers of mice for up to two weeks, and a serum IgG response was induced both to the Salmonella and to the inserted chlamydial epitopes. By contrast, intravenous inoculation was ineffective. Although these LamB fusions proved only weakly immunogenic, this approach should be useful for investigating the ability of attenuated $S$. typhimurium vaccines incorporating chlamydial epitopes to stimulate protective mucosal immunity in the mouse model of chlamydial salpingitis.
\end{abstract}

\section{Introduction}

Chlamydia trachomatis serovars A, B and C are the infectious agents of trachoma, a major cause of preventable blindness world-wide. These three serovars belong either to the B complex (serovar B), or to the C complex (serovars $A$ and $C$ ), according to which subspecies epitopes they express. Trachoma vaccines which use killed whole chlamydiae afford only short term, serovarspecific immunity associated with local tear antibody, and in some cases, when subjects subsequently become infected with heterologous serovars, increase disease severity (reviewed by Schachter \& Dawson, 1978). A subunit vaccine which incorporated protective epitopes towards all three trachoma serovars but excluded antigens which induce damaging hypersensitivity responses (Morrison et al., 1989) might be more successful.

Abbreviations: EB, elementary body; mAb, monoclonal antibody; MOMP, major outer membrane protein; PCR, polymerase chain reaction; RB, reticulate body; TBS, Tris-buffered saline; TTBS, Tween-20-Tris-buffered saline; VS, variable segment.

The nucleotide sequence data reported in this paper have been submitted to the EMBL, GenBank and DDBJ Nucleotide Sequence Databases and assigned the accession number M33536.
Ideally, such a vaccine should generate neutralizing mucosal antibody to the surface of the infectious EB, as well as systemic immunity, in order to prevent initial eye infection before the organisms become sequestered within host cells.

The most promising subunit vaccine candidate is the major outer membrane protein (MOMP), a porin which maintains structural rigidity of the outer envelope, regulates nutrient influx and which controls early intracellular differentiation of the chlamydiae (Bavoil $e t$ al., 1984; Hatch et al., 1984). Immunodominant serovarand subspecies-specific epitopes on MOMP are surfaceexposed, and antibodies to them are neutralizing in vivo (Zhang et al., 1987). By contrast, most species- and genus-specific epitopes on MOMP are inaccessible to antibody (Batteiger et al., 1986; Kuo \& Chi, 1987; Zhang et al., 1987; Conlan et al., 1989) and thus nonneutralizing, although a surface-exposed-species-reactive MOMP epitope has been described (Collett $e t$ al., 1989). Two B-complex-specific, surface-exposed linear epitopes $\left(B_{1}\right.$ and $B_{2}$ ) have been identified within variable segment 4 (VS4) of serovar B MOMP (Conlan et al., 1989). By contrast, a C-complex-specific, surfaceexposed epitope is located within VS1 of serovar A 
MOMP (Hayes et al., 1990). Rabbit antisera to synthetic peptide analogues of epitopes $\mathbf{B}_{1}, \mathbf{B}_{2}$ and a modified analogue of the $\mathrm{C}$-complex specific epitope react with the surfaces of live chlamydiae of all three trachomacausing serovars, as demonstrated by immunogold transmission electron microscopy (Conlan et al., 1989 and unpublished results). Thus, a subunit vaccine incorporating these epitopes might protect against trachoma infection, especially if such a vaccine was engineered to elicit local, as well as systemic immunity. The necessary antigenic persistence for stimulating mucosal immunity might be achieved using a suitable live, attenuated vaccine organism.

A mouse model for chlamydial infection is available (Tuffrey et al., 1986). When progesterone-treated C3H mice are inoculated into the uterus or ovarian bursa with a human genital tract isolate of $C$. trachomatis, they develop salpingitis and infertility. Since successful antigenic priming at any mucosal site, for example the gut, should protect against challenge at any other mucosal site, this model is suitable for preliminary trials of trachoma vaccine candidates.

The LamB protein of E. coli was chosen as a suitable vehicle for expression of chlamydial epitopes in the outer membrane of a live bacterial vaccine. LamB is a $47 \mathrm{kDa}$ outer membrane protein which, like MOMP, is a porin and which regulates maltose transport in $E$. coli. The lamB gene has been cloned, placed under tac promoter control (Bouges-Bocquet et al., 1984) and engineered to create a unique BamHI site allowing insertion of foreign epitopes at amino acid position 153 of the mature LamB protein (Boulain et al., 1986). Epitopes inserted at this site are located on a surface-exposed loop (Boulain $e t$ al., 1986; Charbit et al., 1991). As a vaccine vector for the modified LamB protein, we chose attenuated, nonreverting aroA strains of Salmonella. These organisms colonize the mouse gut but do not multiply, protecting mice against subsequent infection with the virulent parent strains (Hoiseth \& Stocker, 1981). AroA strains have been used to elicit immune responses in mice to a variety of foreign antigens expressed both cytoplasmically (Brown et al., 1987; Poirier et al., 1988; Clements et al., 1986; Fairweather et al., 1990), and at the cell surface (Charbit et al., 1987; Maskell et al., 1987; Wu et al., 1989). This approach is potentially useful in humans since variously attenuated strains of Salmonella typhi, including $\operatorname{aro} A$, are undergoing trials as live oral vaccines for use in humans (Tacket et al., 1990).

In this study, oligonucleotides encoding two Bsubspecies epitopes of $C$. trachomatis were synthesized and cloned into the $\operatorname{lam} B$ gene. Both epitopes were incorporated into recombinant LamB proteins expressed in $E$. coli and $S$. typhimurium, and were recognized in immunoblots by polyclonal antibodies raised against synthetic peptide analogues. When administered orally to the strain of mouse used to study chlamydial salpingitis, serum IgG responses to $S$. typhimurium and C. trachomatis were induced but neither mucosal response nor serum IgA was detected.

\section{Methods}

Bacterial strains and vectors. Escherichia coli JM109 (Yanisch-Perron et al., 1985) Epicurean competent cells were purchased from Northumbria Biologicals Limited. Salmonella typhimurium strains LB5010 ( $\mathrm{galE}^{-}, r^{-}, \mathrm{m}^{+}$; Bullas \& Ryo, 1983) and SL3261 (aroA; Hoiseth \& Stocker, 1981) and bacteriophage P22 (Schmieger, 1972) were kind gifts of Dr G. Dougan (Wellcome Research Laboratories, Beckenham, UK). The lamB vector, pAJC264 (Boulain et al., 1986) was a kind gift of Dr M. Hofnung (Institut Pasteur, Paris, France).

Enzymes. Restriction endonucleases, T4 DNA ligase and calf intestinal phosphatase were obtained from Boehringer Mannheim. T4 polynucleotide kinase was obtained from Gibco-BRL. All enzymes were used as recommended by the manufacturer.

Oligonucleotides. Complementary oligonucleotide pairs encoding epitopes $\mathbf{B}_{1}$ and $\mathbf{B}_{2}$ were synthesized which utilized $E$. coli high expression codon preferences (Grosjean \& Fiers, 1982). The oligonucleotide pairs contained BamHI-compatible ends which recreated a BamHI site only at the $5^{\prime}$ end of the insert when cloned into BamHI cleaved vector. Positioning of cloning sites on the oligonucleotides resulted in the addition of a proline to the $\mathrm{N}$-terminus and an asparagine to the $C$-terminus of each epitope. Epitopes $B_{1}, B_{2}$ and the corresponding oligonucleotide sequences are shown in Fig. 1. Oligonucleotides were synthesized using $\beta$-cyanoethyl phosphoramidite chemistry on an automated DNA synthesizer (Applied Biosystems Inc., Foster City, CA).

DNA manipulations. Complementary oligonucleotide pairs were simultaneously phosphorylated with $\mathrm{T} 4$ polynucleotide kinase and hybridized together in $70 \mathrm{mM}-\mathrm{Tris} / \mathrm{HCl}$ (pH 7.6), $10 \mathrm{mM}-\mathrm{MgCl}_{2}, 5 \mathrm{mM}$ DTT and $500 \mu \mathrm{M}$-ATP overnight at $37^{\circ} \mathrm{C}$. Oligonucleotide hybrids were ligated with BamHI-cut, dephosphorylated pAJC264 in $66 \mathrm{~mm}$ Tris/ $\mathrm{HCl}$ (pH 7.5), $5 \mathrm{mM}-\mathrm{MgCl}_{2}, 5 \mathrm{~mm}$-DTT and $1 \mathrm{mM}$-ATP overnight at $4{ }^{\circ} \mathrm{C}$. Epicurean JM109 was transformed with the recombinant plasmids according to the supplier's instructions. The constructs made are summarized in Table 1. Recombinant plasmids were prepared by alkaline lysis (Birnboim \& Doly, 1979) and purified through NACS Prepac cartridges (Gibco-BRL). S. typhimurium LB5010, a galactose epimerase mutant, was transformed with recombinant plasmids as follows: S. typhimurium LB5010, grown in LB-broth to an $\mathrm{OD}_{550}$ of 0.5 , was pelleted, resuspended in 0.5 vols of $100 \mathrm{mM}-\mathrm{MgCl}_{2}$, incubated on ice for $20 \mathrm{~min}$, pelleted again, then resuspended in one-fiftieth of the original volume of $100 \mathrm{mM}-\mathrm{CaCl}_{2}$. Competent cells $(200 \mu \mathrm{l})$ were added to $20 \mathrm{ng}$ of plasmid and kept on ice for $20 \mathrm{~min}$, at room temperature for $20 \mathrm{~min}$, and on ice for $40 \mathrm{~min}$. The cells were heat-shocked for $2 \mathrm{~min}$ at $42{ }^{\circ} \mathrm{C}$, then incubated for one hour at $37^{\circ} \mathrm{C}$ with $800 \mu \mathrm{l} \mathrm{LB}$-broth, and plated onto LB-agar containing $100 \mu \mathrm{g}$ ampicillin $\mathrm{ml}^{-1}$. Overnight cultures $(200 \mu \mathrm{l}$ samples) of recombinant $S$. typhimurium were incubated with dilutions of bacteriophage P22 and plated onto LB-agar containing ampicillin $\left(100 \mu \mathrm{g} \mathrm{ml}^{-1}\right)$. Recombinant bacteriophage P22 were harvested from plates of confluent plaques. $S$. typhimurium SL3261 (aroA) was transduced with recombinant $\phi \mathrm{P} 22$ as follows: $200 \mu \mathrm{l}$ of $S$. typhimurium SL3261 grown overnight in LB-broth 
supplemented with $1 \mathrm{mM}-\mathrm{CaCl}_{2}$ was incubated with $1 \mu \mathrm{l}$ of the recombinant phage stock for one hour at $37^{\circ} \mathrm{C}$. The mixture was spread onto LB-agar containing ampicillin $\left(75 \mu \mathrm{g} \mathrm{ml}^{-1}\right)$ and 5 mM-EGTA. In each of the three bacterial hosts, ampicillin resistant colonies were screened by immunoblotting for expression of the required epitopes. Inserts were checked for correct frame and orientation by DNA sequencing.

Antisera. Rabbit polyclonal antisera were raised against synthetic peptide analogues of epitopes $\mathbf{B}_{1}$ and $\mathbf{B}_{2}$ as previously described (Conlan et al., 1989).

Immunoblotting. E. coli strains $\left(400 \mu \mathrm{g}\right.$ protein $\left.\mathrm{ml}^{-1}\right)$ were disrupted by boiling for $10 \mathrm{~min}$ in $0.0625 \mathrm{M}$-Tris/HCl $(\mathrm{pH} 6.8), 2 \%$ (w/v) SDS, $10 \%$ (v/v) glycerol, $5 \%$ (v/v) $\beta$-mercaptoethanol and $0.001 \%(\mathrm{w} / \mathrm{v})$ bromophenol blue. Whole cell lysates were separated by SDS-PAGE on $12.5 \%(\mathrm{w} / \mathrm{v})$ polyacrylamide using the Laemmli (1970) buffer system. Denatured proteins were electroblotted onto nitrocellulose (Schleicher \& Schuell) at $100 \mathrm{~mA}$ for $90 \mathrm{~min}$ using a semi-dry blotter (Ancos, Denmark) (Khyse-Andersen, 1984). The nitrocellulose was then blocked overnight at $4{ }^{\circ} \mathrm{C}$ in Tris-buffered saline (TBS; $2 \cdot 24 \mathrm{~g}$ Tris $1^{-1}, 26.24 \mathrm{~g} \mathrm{NaCl}^{-1}, \mathrm{pH} 7.5$ ) containing $0.05 \%$ (v/v) Tween-20(TTBS) and $5 \%(\mathrm{w} / \mathrm{v})$ dried skimmed milk (Marvel). Blots were incubated for $3 \mathrm{~h}$ at room temperature with primary antibodies diluted $1: 200$ in TTBS containing $5 \%(\mathrm{w} / \mathrm{v})$ Marvel, then washed $3 \times 5 \mathrm{~min}$ in TTBS. The blots were incubated for $1 \mathrm{~h}$ at room temperture with goat antirabbit IgG-alkaline-phosphatase conjugate (Bio-Rad) diluted 1:3000 in TTBS containing $5 \%$ Marvel, followed by washing for $4 \times 5 \mathrm{~min}$ in TTBS, then $3 \times 5 \mathrm{~min}$ in TBS. Antigen-antibody complexes were visualized using 5-bromo-4-chloro-3-indolyl phosphate and nitroblue tetrazolium (Sigma) and the reactions were stopped by washing the blots in distilled water.

DNA sequencing. Cloning junctions and inserted DNA of recombinant plasmids were sequenced by the dideoxy chain termination method modified for double stranded DNA (Zhang et al., 1988). Briefly, $3 \mu \mathrm{g}$ of plasmid DNA was incubated for $5 \mathrm{~min}$ at room temperature in $0.2 \mathrm{M}$ $\mathrm{NaOH}, 0.2 \mathrm{~mm}$-EDTA (total volume, $20 \mu \mathrm{l}$ ). The solution was neutralized by addition of $2 \mu \mathrm{l} 2 \mathrm{M}-\mathrm{NH}_{4}$-acetate (pH 4.6) and DNA was precipitated with $60 \mu 1100 \%$ ethanol. The DNA was pelleted, washed with $80 \%$ ethanol, repelleted, then sequenced using modified $\mathrm{T} 7$ polymerase (Sequenase; Cambridge Bioscience) and $\left[\alpha^{-35}\right.$ S $]$ ATP (410 $\mathrm{Ci} \mathrm{mmol}^{-1} ; 1.5 \times 10^{13} \mathrm{~Bq} \mathrm{mmol}^{-1}$; Amersham). The $17 \mathrm{mer}$ oligonucleotides (5'AACTCTCTCTGGCAGCA and 5'TTCGCGGTTTCGTTGGT) used to prime sequences in both directions across the inserts were based on the published sequence of the LamB gene (Clement \& Hofnung, 1981).

Separation of cytoplasmic and outer membranes of E. coli JM109 and S. typhimurium SL3261. Cytoplasmic and outer membranes of recombinant $E$. coli and $S$. typhimurium SL3261 expressing LamB containing $B_{1}+B_{2}$ were separated by the method of Osborn \& Munson (1974). Briefly, $250 \mathrm{ml}$ cultures in LB broth, induced with $0.1 \mathrm{mM}$-IPTG were pelleted, resuspended in $15 \mathrm{ml} 0.75 \mathrm{M}$-sucrose, $10 \mathrm{~mm}$-Tris-acetate $\mathrm{pH} 7 \cdot 5,100 \mu \mathrm{g}$ lysozyme $\mathrm{ml}^{-1}$ and incubated on ice for $2 \mathrm{~min}$. Cells were spheroplasted by addition of $30 \mathrm{ml}$ ice-cold $1.5 \mathrm{~mm}$-EDTA over $10 \mathrm{~min}$, then sonicated to lyse the spheroplasts. After a clearing spin, membranes were washed twice by centrifuging through $0.25 \mathrm{M}$-sucrose, $3.3 \mathrm{~mm}$-Tris/ $\mathrm{HCl}$ and $1 \mathrm{~mm}$-EDTA for $2 \mathrm{~h}$ at $100000 \mathrm{~g}$ at $4{ }^{\circ} \mathrm{C}$. Cytoplasmic and outer membrane fractions were separated by centrifugation at $130000 \mathrm{~g}$ for $16 \mathrm{~h}$ at $4{ }^{\circ} \mathrm{C}$ through a $30-55 \%$ sucrose gradient. After centrifugation each gradient was collected in 30 fractions. Total protein content of each fraction was measured by modified Lowry assay (Ohnishi \& Barr, 1978) and fractions containing protein peaks were subjected to PAGE followed by either silver staining to detect LPS (Tsai \& Frasch, 1982) or immunoblotting to detect recombinant LamB.

Immunization of mice with live aroA mutants of $S$. typhimurium expressing $B_{1}+B_{2}$ recombinant LamB protein. Mice were immunized with a $\mathbf{B}_{1}+\mathbf{B}_{2}$ recombinant which possessed smooth LPS. A stock of the immunizing strain was grown in LB broth containing ampicillin (125 $\mu \mathrm{g} \mathrm{m}^{-1}$ ) and $0.1 \mathrm{mM}$-IPTG $\left(16 \mathrm{~h}\right.$ at $37^{\circ} \mathrm{C}$ without shaking). This was harvested by centrifugation $(600 \mathrm{~g})$ and resuspended in PBS (Dulbecco A) containing 10\% (v/v) glycerol as a cryopreservative to a total count of $2 \times 10^{11} \mathrm{ml}^{-1}$ (at $60 \%$ viability). Cells were stored frozen at $-20{ }^{\circ} \mathrm{C}$ until required. A control culture of non-recombinant $S$. typhimurium was similarly prepared. Female $\mathrm{C} 3 \mathrm{H} / \mathrm{He} / \mathrm{Ola}$ mice (Olac Ltd), 6-10 weeks old, were used in all experiments. This mouse strain was chosen because it is known to be susceptible to genital tract infections with human strains of $C$. trachomatis (Tuffrey et al., 1986). On day one, 24 mice were immunized intravenously (i.v.) with $0.1 \mathrm{ml}$ of the $B_{1}+B_{2}$ LamB recombinant diluted in PBS to a total count of $2 \times 10^{6} \mathrm{ml}^{-1}$. A further five mice received an equivalent dose of control $S$. typhimurium aroA. A second group of 24 mice were challenged per os (p.o.) with the recombinant $\left(0 \cdot 1 \mathrm{ml}\right.$ of culture at $2 \times 10^{11} \mathrm{ml}^{-1}$ total count) delivered using a gavage needle. A control group of five mice were similarly immunized with control $S$. typhimurium aroA. Six mice received no vaccine. All mice were housed in separate cages within the same room. At weekly intervals for six weeks, serum was obtained from mice (4 per group) which had received recombinant $B_{1}+B_{2}$ (i.v. or p.o.) by tail-vein venepuncture whilst under metafane anaesthesia. After blood samples had been taken the mice were killed by $\mathrm{CO}_{2}$ anoxia. The liver and spleen were removed whole from each animal aseptically into $10 \mathrm{ml}$ sterile distilled water. The small intestine between the caecum and stomach was removed intact and the contents collected by washing. Sera and clarified gut washes were stored at $-80^{\circ} \mathrm{C}$. Livers and spleens were homogenized for $1 \mathrm{~min}$ in a Colworth stomacher and the resulting macerates plated on LB-agar containing ampicillin for recovery of organisms. On the sixth week following immunization, all control animals were processed as above.

Determination of antibody in sera and gut-washes of immunized mice by amplified ELISA. Antibodies to S. typhimurium aroA and C. trachomatis serovar B were detected by redox-amplified ELISA (Johannsson $e t$ al., 1985). S. typhimurium aroA or C. trachomatis serovar B whole cells at a protein concentration of $10 \mu \mathrm{g} \mathrm{ml}^{-1}$ were coupled to microtitre PVC microtitre trays (Flow laboratories) by overnight incubation in carbonate buffer at $18^{\circ} \mathrm{C}\left(1.6 \mathrm{~g} \mathrm{l}^{-1} \mathrm{Na}_{2} \mathrm{CO}_{3}, 2.95 \mathrm{~g} \mathrm{l}^{-1} \mathrm{NaHCO}_{3}\right.$, $0.2 \mathrm{~g} \mathrm{l}^{-1} \mathrm{NaN}_{3} ; \mathrm{pH} \mathrm{9.6).} \mathrm{Excess} \mathrm{antigen} \mathrm{was} \mathrm{removed} \mathrm{by} \mathrm{washing} \mathrm{the}$ trays three times with $50 \mathrm{~mm}$-ethanolamine $/ 100 \mathrm{~mm}-\mathrm{NaCl}$ (pH adjusted to 10.5 with $100 \mathrm{~mm}$-citric acid). The antigen-coated, washed trays were blocked for $1 \mathrm{~h}$ at $37^{\circ} \mathrm{C}$ with PBS (Dulbecco A) containing $5 \%$ (v/v) normal goat serum $(100 \mu l$ per well). The blocking solution was drained and test sera or gut washes added at $1: 100$ or $1: 5$ dilution respectively $(50 \mu \mathrm{l}$ per well). The diluent was blocking solution containing $0.05 \%(\mathrm{v} / \mathrm{v})$ WI detergent (Sigma). The trays were sealed and incubated for $3 \mathrm{~h}$ at $37^{\circ} \mathrm{C}$, then washed four times. Goat antimouse alkaline phosphatase conjugates specific for IgA or IgG (Zymed laboratories) were added at 1:1000 dilution $(50 \mu \mathrm{l}$ per well) and incubation continued for $\mathbf{4 5} \mathrm{min}$. After a further six washes, NADP substrate (0.2 mM-NADP, $10 \mathrm{~mm}-\mathrm{MgCl}_{2}, 1 \mathrm{~mm}-\mathrm{ZnCl}_{2}, 150 \mathrm{mM}-\mathrm{NaN}_{3}$ in $50 \mathrm{~mm}$ diethanolamine buffer, $\mathrm{pH} 9.5)$ was added $(50 \mu \mathrm{l}$ per well). This solution was filtered through a $0.22 \mu \mathrm{m}$ filter immediately before use. Incubation continued for $40 \mathrm{~min}$ at $18^{\circ} \mathrm{C}$. After this time $100 \mu \mathrm{l}$ amplifier was added to each well. Amplifier solution consisted of $0.2 \mathrm{~g} \mathrm{l}^{-1}$ alcohol dehydrogenase, $0.15 \mathrm{~g} \mathrm{l}^{-1}$ diaphorase, $0.28 \mathrm{~g} \mathrm{l}^{-1} \mathrm{p}$ iodonitrotetrazolium violet (all reagents from Sigma) in $20 \mathrm{~mm}$-sodium phosphate buffer ( $\mathrm{pH} 7 \cdot 2)$ containing $4 \%(\mathrm{v} / \mathrm{v})$ ethanol. The reaction was stopped by addition of $3 \%(\mathrm{v} / \mathrm{v}) \mathrm{H}_{2} \mathrm{SO}_{4}(25 \mu \mathrm{l}$ per well) and the reaction product measured as $A_{495}$. 
(a)

Serovar B VS4:

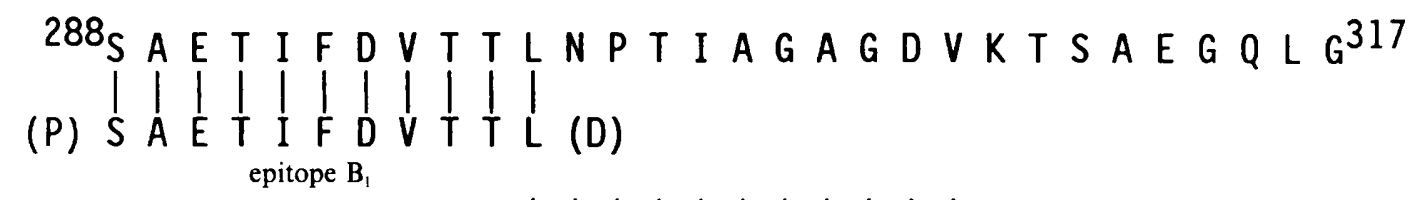

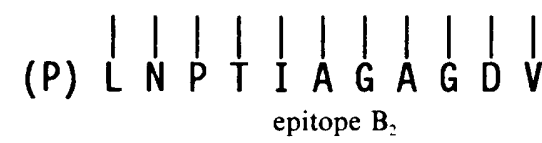

(b)

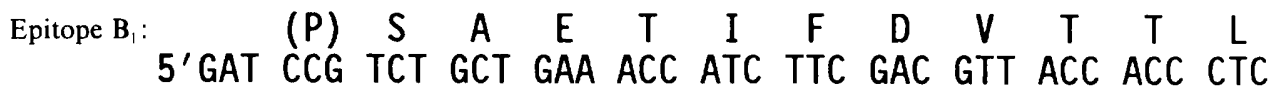

$$
\begin{aligned}
& 3^{\prime} \text { GC AGA CGA CTT TGG TAG AAG CTG CAA TGG TGG GAG CTA G }
\end{aligned}
$$

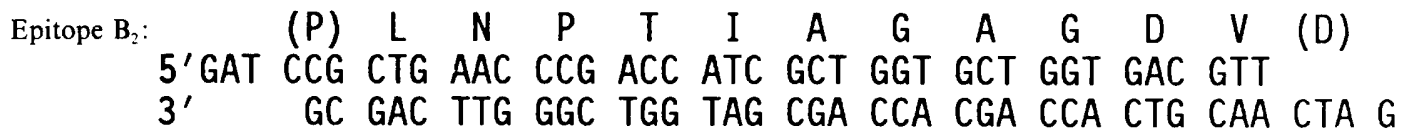

Fig. 1. (a) Sequence of serovar B VS4, showing position of epitopes $\mathbf{B}_{1}$ and $\mathbf{B}_{2}$. (b) Oligonucleotide pairs encoding $\mathbf{B}_{1}$ and $\mathbf{B}_{2}$. Brackets indicate non-native sequence added for cloning.

\section{Results and Discussion}

\section{Expression of epitopes in E. coli}

C. trachomatis epitopes $\mathrm{B}_{1}$ and $\mathrm{B}_{2}$ are shown in Fig. 1; they are identical to the sequences occurring in $C$. trachomatis serovar B/Jali-20/OT VS4 (Hayes et al., 1990). Sequence $B_{1}$ contains the known B-complexspecific, surface-exposed epitope IFDV (Conlan et al., 1988). Sequence $B_{2}$ contains a species-specific epitope, LNPTIA, which is not surface-exposed (Stephens et al., 1988; Conlan et al., 1988; Baehr et al., 1988) as well as an additional surface exposed, B-complex specific region AGDV (Conlan et al., 1989). Epitopes $\mathbf{B}_{1}$ and $\mathbf{B}_{2}$ were expressed as fusions with LamB both individually and in tandem, as shown in Table 1 . An additional sequence from VS1 of serovar A, containing serovar A- and Csubspecies-specific epitopes (Hayes et al., 1990) was expressed in $S$. typhimurium aroA but was not used for animal inoculations since it was poorly detected in Western blots and the recombinant salmonellae expressing this epitope consistently possessed rough LPS.

Immunoblots of $E$. coli strains expressing epitopes $B_{1}$ and $B_{2}$ as recombinant LamB proteins are shown in Fig. $2(a$ and $b$ ). In VS4 of serovar B MOMP, the sequence ${ }^{288}$ SAETIFDVTTLNPTIAGAGDV ${ }^{308}$ contains epitopes $B_{1}$ (residues 288-298) and $B_{2}$ (residues 298-308) which overlap each other by one amino acid. Interestingly, the double construct $B_{1}+B_{2}$ in the reversed order, ie (P)LNPTIAGAGDV(DP)SAETIFDVTTL(D) ap-
Table 1. Summary of chlamydial epitopes fused with LamB Brackets indicate non-natural sequences.

\begin{tabular}{llc}
\hline \hline Epitopes & \multicolumn{1}{c}{ Amino acid sequence } & $\begin{array}{c}\text { No. of } \\
\text { residues }\end{array}$ \\
\hline $\mathbf{B}_{1}$ & (P)SAETIFDVTTL(D) & 13 \\
$\mathbf{B}_{2}$ & (P)LNPTIAGAGDV(D) & 13 \\
$\mathbf{B}_{1}+\mathbf{B}_{2}$ & (P)SAETIFDVTTL(DP)LNPTIAGAGDV(D) & 26 \\
\hline \hline
\end{tabular}

peared to express both epitopes, since a non-truncated recombinant protein was obtained. However, only the proximal $\mathrm{B}_{2}$ was detected by immunoblotting (data not shown). DNA sequencing confirmed the correct orientation of both epitopes in the double recombinant. Presumably the lack of reactivity of $B_{1}$ in this construct reflects stoichiometric constraints on the ordering of epitopes within the LamB vector.

\section{Expression of epitopes in S. typhimurium SL3261}

S. typhimurium SL3261 (aroA) was transduced with $\phi \mathrm{P} 22$ carrying recombinant plasmids, since direct transformation of smooth Salmonella strains is very inefficient (MacLachlan \& Sanderson, 1985) and selects for rough mutants (Brown et al., 1987). The receptor for $\phi \mathrm{P} 22$ is not present on rough salmonellae, ensuring that transductants are smooth. Only smooth salmonellae will 
colonize mice. Fig. $2 c$ shows immunoblots of $S$. typhimurium SL3261 expressing recombinant LamB fused with epitopes $\mathbf{B}_{1}+\mathbf{B}_{2}$. These epitopes were

(a)

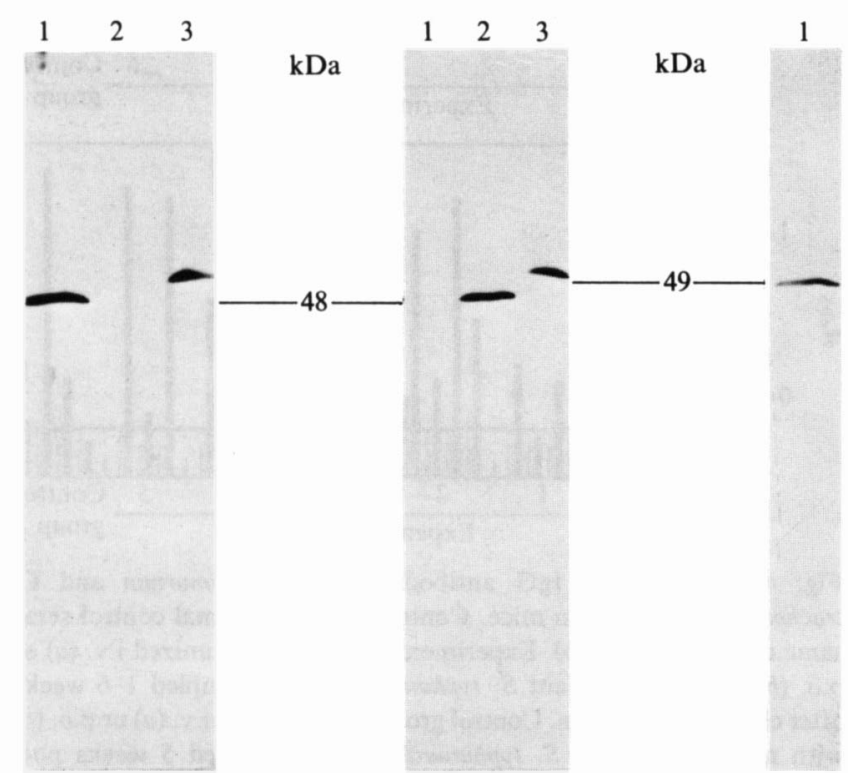

Fig. 2. $(a, b) E$. coli recombinants expressing LamB fusion proteins containing: lane 1, $\mathrm{B}_{1}$; lane 2, $\mathrm{B}_{2}$; lane 3, $\mathrm{B}_{1}+\mathrm{B}_{2}$. (a) Probed with anti$\mathbf{B}_{1}$. (b) Probed with anti- $\mathrm{B}_{2}$. (c) $S$. typhimurium aro $A$ recombinant expressing LamB fusion protein containing $B_{1}+B_{2}$, probed with anti$\mathbf{B}_{1}$. Approximate molecular masses are shown.

(a)

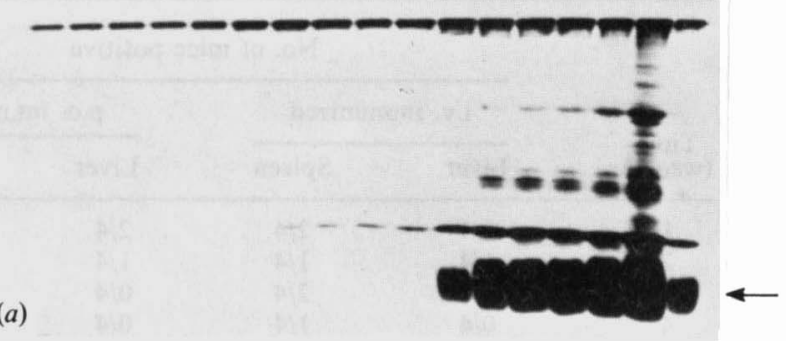

(c)

Fig. 3. Cytoplasmic and outer membranes of recombinant $\left(\mathrm{B}_{1}+\mathrm{B}_{2}\right)$ E. coli $(a, c)$ of $S$. typhimurium aro $A(b, d)$ separated by sucrose gradient centrifugation and collected as fractions, which were then subjected to PAGE and either silver stained $(a, b)$ or immunoblotted and probed with anti- $\mathrm{B}_{1}(c, d)$. Fractions from the top of each gradient to the bottom were loaded from left to right on the gels. Arrows indicate LPS and recombinant LamB. expressed in S. typhimurium SL3261 at equivalent levels to those observed in E. coli JM109.

\section{Location of recombinant LamB proteins within the bacterial outer membrane}

To verify the location of the expressed proteins, cytoplasmic and outer membrane fractions of recombinant $E$. coli and $S$. typhimurium were separated by sucrose density gradient centrifugation, then subjected to PAGE followed by silver staining (Fig. $3 a$ and $b$ ). The outer membrane component LPS was located in fractions towards the bottom of the gradient. In identical gels immunoblotted and probed with anti- $\mathrm{B}_{1}$ (Fig. $3 c$ and $d$ ), the recombinant LamB protein was located exclusively in those fractions which contained LPS, indicating that it is present in the outer membrane in both $E$. coli and $S$. typhimurium. From the proposed model of LamB folding (Boulain et al., 1986; Charbit et al., 1991) it would be expected that the inserted $C$. trachomatis epitopes should reside within a surface-exposed loop. However, attempts to label these epitopes at the surfaces of recombinant $E$. coli and $S$. typhimurium with immunogold were unsuccessful. The long side chain of smooth LPS may prevent antibody binding to the surface-exposed LamB, blocking surface labelling of the recombinant bacteria with immunogold. However, Brown et al. (1987) demonstrated that expression at the surface of salmonellae is not necessary to provoke B- and T-cell responses to cloned proteins.

(b)

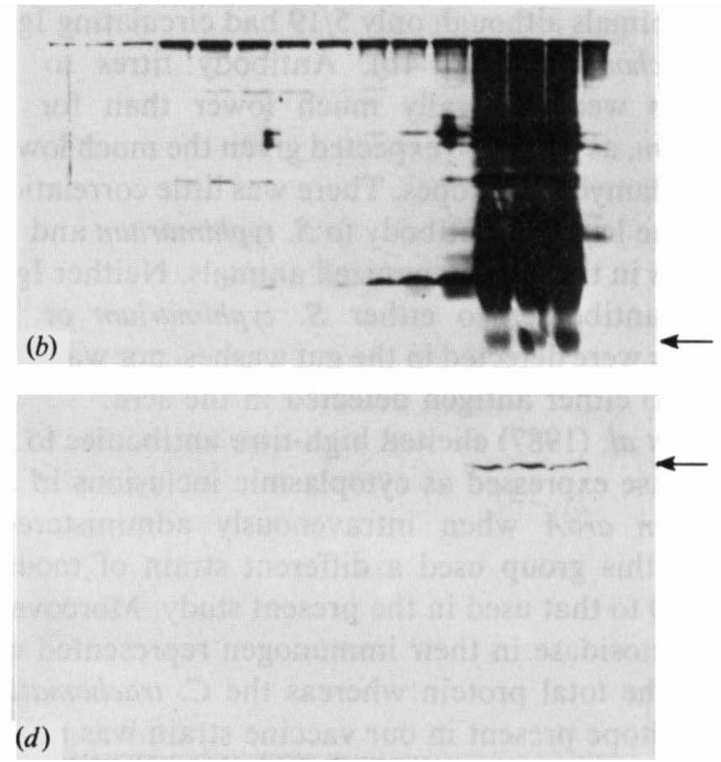

(d) 
Recovery of $B_{1}+B_{2}$ LamB recombinant $S$. typhimurium aro $A$ mutants from immunized mice

These were the first experiments to use recombinant chlamydial antigens expressed in salmonellae to elicit immune responses in the mouse model of chlamydial infection. Ampicillin-resistant bacteria were recovered from the livers of mice immunized i.v. for up to two weeks post-challenge and from the spleens of these animals for up to four weeks (Table 2). Bacteria were also recovered from the livers of p.o. immunized mice for up to two weeks. However, no bacteria were isolated from the spleens of p.o. immunized animals after the first week. In all cases the numbers of bacteria recovered were low (10-30 organisms per organ) and they were confirmed to be carrying the recombinant $\operatorname{lam} B$ plasmid by PCR, using as primers the lamB-specific oligonucleotides described above (data not shown).

\section{Detection of antibodies in immunized mice to}

\section{$S$. typhimurium and C. trachomatis}

A live attenuated $S$. typhimurium aro $A$ mutant containing recombinant $\mathrm{LamB}$ protein incorporating $C$. trachomatis epitopes $B_{1}+B_{2}$ was assessed for its ability to generate anti-chlamydial antibodies when inoculated into mice. Two routes of administration were tried; i.v. immunization with $S$. typhimurium aro $A$ expressing LamB $\left(B_{1}+B_{2}\right)$, which produced circulating IgG antibody to $S$. typhimurium and to $C$. trachomatis in only 5/24 and $3 / 24$ animals respectively (Fig. $4 a$ ), and oral immunization, which produced circulating IgG to $S$. typhimurium in $15 / 19$ animals although only $5 / 19$ had circulating IgG to $C$. trachomatis (Fig. $4 b$ ). Antibody titres to $C$. trachomatis were generally much lower than for $S$. typhimurium, as would be expected given the much lower mass of chlamydial epitopes. There was little correlation between the levels of antibody to $S$. typhimurium and $C$. trachomatis in the p.o. immunized animals. Neither IgA nor $\mathrm{IgG}$ antibodies to either $S$. typhimurium or $C$. trachomatis were detected in the gut washes, nor was IgA antibody to either antigen detected in the sera.

Brown et al. (1987) elicited high-titre antibodies to $\beta$ galactosidase expressed as cytoplasmic inclusions in $S$. typhimurium aro $A$ when intravenously administered. However, this group used a different strain of mouse $(\mathrm{BIOXA} / \mathrm{J})$ to that used in the present study. Moreover, the $\beta$-galactosidase in their immunogen represented up to $2 \%$ of the total protein whereas the $C$. trachomatisspecific epitope present in our vaccine strain was much less than this as judged subjectively by the quantity of LamB present on SDS-PAGE profiles.

By contrast to i.v. immunization, p.o. administration of the recombinant LamB aroA strain resulted in
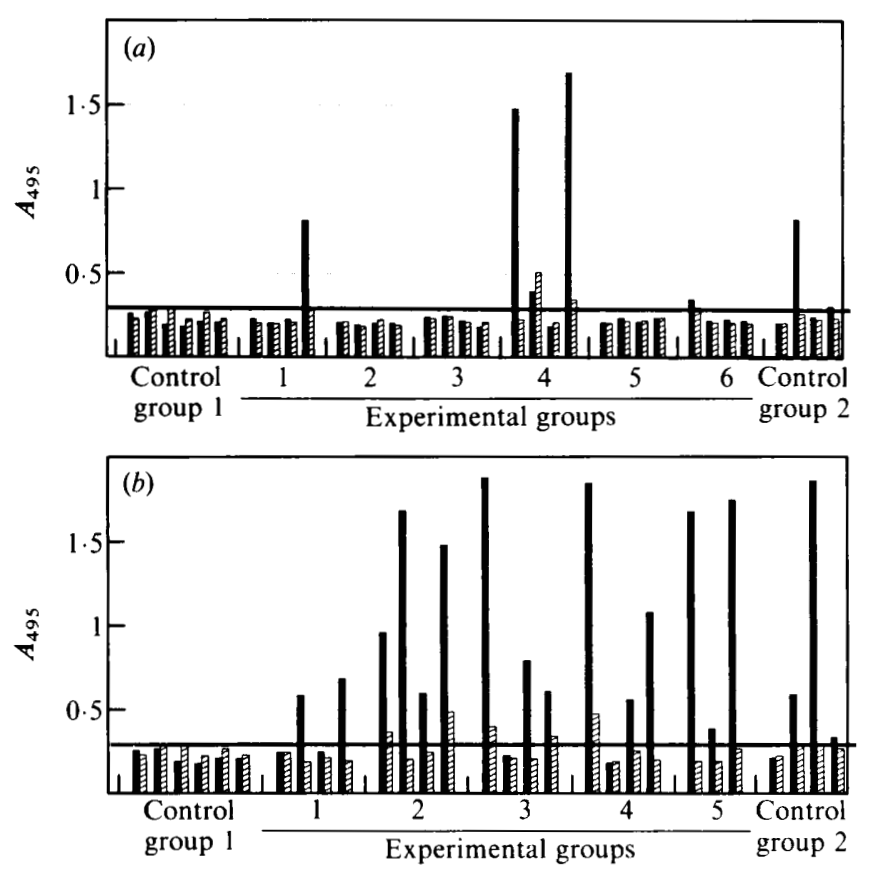

Fig. 4. Detection of IgG antibodies to $S$. typhimurium and $C$. trachomatis serovar B in mice. Control group 1, normal control sera; same mice in $(a)$ and $(b)$. Experimental groups; immunized i.v. $(a)$ or p.o. $(b)$ with recombinant $S$. typhimurium aroA, sampled 1-6 weeks after challenge as shown. Control group 2, inoculated i.v. (a) or p.o. (b) with non-recombinant $S$. typhimurium aro $A$, sampled 5 weeks post challenge. Each pair of columns represents a single mouse. Filled columns represent IgG to $S$. typhimurium; hatched columns represent IgG to $C$. trachomatis.

Table 2. Recovery of bacteria from livers and spleens of mice immunized with $S$. typhimurium LamB $\left(B_{1}+B_{2}\right)$

\begin{tabular}{|c|c|c|c|c|}
\hline \multirow{3}{*}{$\begin{array}{c}\text { Time } \\
\text { (weeks) }\end{array}$} & \multicolumn{4}{|c|}{ No. of mice positive } \\
\hline & \multicolumn{2}{|c|}{ i.v. immunized } & \multicolumn{2}{|c|}{ p.o. im nunized } \\
\hline & Liver & Spleen & Liver & Spleen \\
\hline 1 & $2 / 4$ & $2 / 4$ & $2 / 4$ & $1 / 4$ \\
\hline 2 & $1 / 4$ & $1 / 4$ & $1 / 4$ & $0 / 4$ \\
\hline 3 & $0 / 4$ & $2 / 4$ & $0 / 4$ & $0 / 4$ \\
\hline 4 & $0 / 4$ & $1 / 4$ & $0 / 4$ & $0 / 4$ \\
\hline 5 & $0 / 4$ & $0 / 4$ & $0 / 3^{*}$ & $0 / 3^{*}$ \\
\hline 6 & $0 / 4$ & $0 / 4$ & $\mathrm{NT}^{*}$ & $\mathrm{NT}^{*}$ \\
\hline
\end{tabular}

* Five mice in the p.o. immunized group died during the experiment and were not available for testing.

NT, not tested.

seroconversion of $\operatorname{IgG}$ antibody to $S$. typhimurium in the majority of mice. This may simply be a reflection of the larger dose of bacteria given p.o. compared to i.v.; however, it was not accompanied by increased colonization of the liver or spleen. Oral immunization produced an antibody response to $C$. trachomatis in significantly more animals than did i.v. immunization. However, the 
total number of mice responding and the antibody titres remained low. Charbit et al. (1987) also found only low levels of antibody to a hepatitis B virus epitope inserted into the LamB protein, although this group used $E$. coli rather than $S$. typhimurium as the bacterial host. Leclerc et al. (1989) found the route of inoculation to be important; i.v. and i.p. administration of live recombinant $E$. coli being more effective than subcutaneous administration, however, mucosal immunity was not sought by those authors.

Surprisingly, no IgA antibody to $C$. trachomatis or to $S$. typhimurium was found in any of the test samples, including the sera. Maskell et al. (1987) using $S$. typhimurium aroA mutants expressing the B subunit of $E$. coli heat labile toxin, demonstrated a consistent $\operatorname{IgA}$ response in both the sera and gut washes of recipient $\mathrm{Balb} / \mathrm{C}$ mice. In that study, the livers and spleens of orally-immunized mice were colonized by bacteria for up to 5 weeks, longer than in the present study, which might partly explain the differences in IgA production. Sigwart et al. (1989) also demonstrated IgA antibodies to $S$. dublin aro $A$ in orally immunized Balb/C mice. In their study, colonization of the liver and spleen was similar to the results reported here, but $S$. dublin was recovered from the small intestine for up to 3 weeks following oral administration. In our study, the recombinant $S$. typhimurium was cleared rapidly $(8 \mathrm{~d})$ from the small intestine of $\mathrm{C} 3 \mathrm{H} / \mathrm{He} / \mathrm{Ola}$ mice. Long-term colonization of the small intestine and particularly the gut-associated lymphoid tissue (GALT) should favour a local IgA response, thus the transient passage of $S$. typhimurium through the gut observed here is probably an insufficient stimulus to elicit secretory IgA. This may reflect the mouse strain we used; $\mathrm{C} 3 \mathrm{H} / \mathrm{He} / \mathrm{Ola}$ mice are susceptible to chlamydial salpingitis (Tuffrey et al., 1986) but are less susceptible to natural $S$. typhimurium infections than Balb/C mice (Hormaeche, 1979). Moreover, surface expression of the recombinant LamB protein might also alter the colonization properties of $S$. typhimurium. Thus the mouse and Salmonella strain, the carrier protein and the properties of the inserted epitopes are all likely to influence the immunogenicity of attenuated Salmonella constructs in mice.

At least one attenuated Salmonella, S. typhi Ty21a, has already proved acceptable for use in man. In some systems Salmonella vectors have achieved adequate mucosal immunity. Our results suggest this may not be true of all systems, indicating a need to modify our vaccination strategy if effective mucosal immunization is to be achieved. The choice of mouse strain is limited by murine genotypic factors affecting the establishment of colonization and chlamydial salpingitis. We believe that the strategy should be to identify a stable Salmonella host capable of colonizing the mouse intestine for 3-4 weeks following oral administration. There is a considerable range of $S$. typhimurium and $S$. enteritidis strains to choose from (reviewed by Curtiss et al., 1989). Secondly, the ability of the chlamydial-Salmonella recombinant to colonize the mouse gut should be determined prior to immunization and challenge studies. Finally, incorporation of T-cell epitopes of MOMP (Allen et al., 1990; Holland et al., 1990) as well as important neutralizing epitopes from other chlamydial surface antigens may enhance the immunogenicity of the constructs. Brown et al. (1987) have demonstrated that cloned antigens expressed in aroA mutants of $S$. typhimurium can induce cellular as well as humoral immune responses. Each model system of human infection may pose its own problems. We believe such studies to be of fundamental importance, given the present inability to control a large number of diseases affecting respiratory, mucosal and ocular surfaces by immunization.

We wish to thank Dr M. Hofnung for the gift of pAJC264 and Dr G. Dougan for the gifts of Salmonella strains and bacteriophage P22. This work was supported by a grant from the Edna McConnell Clark Foundation, New York.

\section{References}

Allen, J. E., Beatty, P. R. \& Stephens, R. S. (1990). Recombinant fusion proteins define $T$-cell antigenic sites on the major outer membrane protein of Chlamydia trachomatis. In Chlamydial Infections - Proceedings of the Seventh International Symposium on Human Chlamydial Infections, pp. 101-104. Edited by W. R. Bowie, H. D. Caldwell, R. P. Jones, P.-A. Mardh, G. L. Ridgway, J. Schachter, W. E. Stamm \& M. E. Ward. Cambridge: Cambridge University Press.

Baehr, W., Zhang, Y.-X., Joseph, T., Su, H., Nano, F. E., Everett, D. E. \& Caldwell, H. D. (1988). Mapping antigenic domains expressed by Chlamydia trachomatis major outer membrane protein (MOMP) genes. Proceedings of the National Academy of Sciences of the United States of America 85, 4000-4004.

Batteiger, B. E., Newhall, W. J., Terho, P., Wilde, C. E. \& Jones, R. B. (1986). Antigenic analysis of the major outer membrane protein of Chlamydia trachomatis with murine monoclonal antibodies. Infection and Immunity 53, 530-533.

Bavoll, P., Ohlin, A. \& Schachter, J. (1984). Role of disulfide bonding in outer membrane structure and permeability in Chlamydia trachomatis. Infection and Immunity 44, 479-485.

BIRNBOIM, H. C. \& DoLY, J. (1979). Rapid alkaline extraction procedure for screening recombinant plasmid DNA. Nucleic Acids Research 7, 1513-1523.

Bouges-Bocquet, B., Villarroya, H. \& Hofnung, M. (1984). Linker mutagenesis in the gene of an outer membrane protein of Escherichia coli, LamB. Journal of Cellular Biochemistry 24, 217-228.

Boulain, J. C., Charbit, A. \& Hofnung, M. (1986). Mutagenesis by random linker insertion into the lamB gene of Escherichia coli K12. Molecular and General Genetics 205, 339-348.

Brown, A., Hormaeche, C. E., Demarco de Hormaeche, R., Winther, M., Dougan, G., Maskell, D. J. \& Stocker, B. A. D. (1987). An attenuated aroA Salmonella typhimurium vaccine elicits humoral and cellular immunity to cloned $\beta$-galactosidase in mice. Journal of Infectious Diseases 155, 86-92.

Bullas, L. R. \& RYo, J. I. (1983). Salmonella typhimurium LT2 strains which are $\mathrm{r}^{-} \mathrm{m}^{+}$for all three chromosomally located systems of DNA restriction and modification. Journal of Bacteriology 156, 471-474. 
Charbit, A., Sobczak, E., Michel, M.-L., Molla, A., Tiollais, P. \& HofNung, M. (1987). Presentation of two epitopes of the pre-S2 region of hepatitis B virus on live recombinant bacteria. Journal of Immunology 139, 1658-1664.

Charbit, A., Ronca, J., Michel, V., Werts, C. \& Hofnung, M. (1991). Permissive sites and topology of an outer membrane protein with a reporter epitope. Journal of Bacteriology 173, 262-275.

Clement, J. M. \& Hofnung, M. (1981). Gene sequence of the $\lambda$ receptor, an outer membrane protein of E. coli K12. Cell 27, 507-514.

Clements, J. D., Lyon, F. L., Lowe, K. L., Farrand, A. L. \& ElMoRSHIDY, S. (1986). Oral immunization of mice with attenuated Salmonella enteritidis containing a recombinant plasmid which codes for production of the B subunit of heat-labile Escherichia coli enterotoxin. Infection and Immunity 53, 685-692.

Collett, B. A., Newhall, W. J., Jersild, V. R. A. \& Jones, R. B (1989). Detection of surface-exposed epitopes on Chlamydia trachomatis by immune electron electron microscopy. Journal of General Microbiology 135, 85-94.

Conlan, J. W., Clarke, I. N. \& Ward, M. E. (1988). Epitope mapping with solid phase peptides: identification of type-, subspecies-, species- and genus-reactive antibody binding domains on the major outer membrane protein of Chlamydia trachomatis. Molecular Microbiology 2, 673-679.

Conlan, J. W., Ferris, S., Clarke, I. N. \& Ward, M. E. (1989). Surface-exposed epitopes on the major outer membrane protein of Chlamydia trachomatis defined with peptide antisera. Journal of General Microbiology 135, 3219-3228.

Curtiss, R., Kelly, S. M., Gulig, P. A. \& Nakayama, K. (1989). Selective delivery of antigens by recombinant bacteria. Current Topics in Microbiology and Immunology 146, 35-49.

Fairweather, N. F., Chatfield, S. N., Makoff, A. J., Strugnell, R. A., Bester, J., Maskell, D. J. \& Dougan, G. (1990). Oral vaccination of mice against tetanus by use of a live attenuated Salmonella carrier. Infection and Immunity 58, 1323-1326.

Grosjean, H. \& Fiers, W. (1982). Preferential codon usage in prokaryotic genes: the optimal codon-anticodon interaction energy and the selective codon usage in efficiently expressed genes. Gene 18, 199-209.

Hatch, T. P., Allan, I. \& Pearce, J. H. (1984). Structural and polypeptide differences between envelopes of infective and reproductive life cycle forms of Chlamydia spp. Journal of Bacteriology 157 , 13-20.

Hayes, L. J., Pickett, M. A., Conlan, J. W., Ferris, S., Everson, J. S., Ward, M. E. \& Clarke, I. N. (1990). The major outer membrane proteins of Chlamydia trachomatis serovars A and B; intra-serovar amino acid changes do not alter specificities of serovarand $\mathrm{C}$ subspecies-reactive antibody binding domains. Journal of General Microbiology 136, 1559-1566.

HoISETH, S. K. \& StOCKeR, B. A. D. (1981). Aromatic-dependent Salmonella typhimurium are non-virulent and effective as live vaccines. Nature, London 291, 238-239.

Holland, M. J., Clarke, I. N., Ward, M. E., Dockrell, N. D., Viswalingham, N. D., GoH, B. T. S., Allason-Jones, E. \& Mabey, D. C. W. (1990). Human T-cell responses to defined antigens of Chlamydia trachomatis. In Chlamydial Infections - Proceedings of the Seventh International Symposium on Human Chlamydial Infections, pp. 177-180. Edited by W. R. Bowie, H. D. Caldwell, R. P. Jones, P.-A. Mardh, G. L. Ridgway, J. Schachter, W. E. Stamm \& M. E. Ward. Cambridge: Cambridge University Press.

HoRmaEChe, C. E. (1979). Natural resistance to Salmonella typhimurium in different inbred mouse strains. Immunology 37, 311-318.

Johannsson, A., Stanley, C. J. \& Self, C. H. (1985). A fast highly sensitive colorimetric enzyme immunoassay system demonstrating benefits of enzyme amplification in clinical chemistry. Clinica Chimica Acta 148, 119-124.

KHYSE-ANDERSEN, J. (1984). Electroblotting of multiple gels: a simple apparatus without buffer tank for rapid transfer of proteins from polyacrylamide to nitrocellulose. Journal of Biochemical and Biophysical Methods 10, 203-209.
Kuo, C. C. \& CHI, E. Y. (1987). Ultrastructural study of Chlamydia trachomatis surface antigens by immunogold staining with monoclonal antibodies. Infection and Immunity 55, 1324-1328.

LAEMMLI, U. K. (1970). Cleavage of structural proteins during the assembly of the head of bacteriophage T4. Nature, London 227, 680 685 .

leclerc, C., Charbit, A., Molla, A. \& Hofnung, M. (1989). Antibody response to a foreign epitope expressed at the surface of recombinant bacteria: importance of the route of immunization. Vaccine 7, 242-248.

Maclachlan, P. R. \& Sanderson, K. E. (1985). Transformation of Salmonella typhimurium with plasmid DNA: differences between rough and smooth strains. Journal of Bacteriology 161, 442-445.

Maskell, D. J., Sweeney, K. J., O'Callaghan, D., Hormaeche, C. E., LIEW, F. Y. \& Dougan, G. (1987). Salmonella typhimurium aroA mutants as carriers of the Escherichia coli heat-labile enterotoxin B subunit to the murine secretory and systemic immune systems. Microbial Pathogenesis 2, 211-221.

Morrison, R. P., Lying, K. \& CaldWell, H. D. (1989). Chlamydial disease pathogenesis: ocular hypersensitivity elicited by a genusspecific 57-kD protein. The Journal of Experimental Medicine 169, 663-675.

OHNISHI, S. T. \& BARR, J. K. (1978). A simplified method of quantitating proteins using the biuret and phenol reagents. Analytical Biochemistry 86, 193-200.

OSBORN, M. J. \& MUNSON, R. (1974). Separation of inner (cytoplasmic) and outer membranes of gram-negative bacteria. Methods in Enzymology 31, 642-653.

Poirier, T., Kehoe, M. A. \& Beachey, E. H. (1988). Protective immunity evoked by oral administration of attenuated aroA Salmonella typhimurium expressing cloned streptococcal M protein. Journal of Experimental Medicine 168, 25-32.

SCHACHTER, J. \& Dawson, C. (1978). Chlamydial Infections. Littleton, MA: PSG Publishing.

SCHMIEGER, H. (1972). Phage P22 mutants with increased or decreased transduction abilities. Molecular and General Genetics 119, 75-88.

Sigwart, D. F., Stocker, B. A. D. \& Clements, J. D. (1989). Effects of a purA mutation of efficacy of Salmonella live vaccine vectors. Infection and Immunity 57, 1858-1861.

Stephens, R. S., Wagar, E. A. \& Schoolnik, G. K. (1988). High resolution mapping of serovar-specific and common antigenic determinants on the major outer membrane protein of Chlamydia trachomatis. Journal of Experimental Medicine 167, 817-831.

TACKet, C. O., Forrest, B., Morona, R., AtTridge, S. R., Labroody, J., Tall, B. D., ReymanN, M., Rowley, D. \& Levine, M. M. (1990). Safety, immunogenicity, and efficacy against cholera challenge in humans of a typhoid-cholera hybrid vaccine derived from Salmonella typhi Ty 21 a. Infection and Immunity 58, 1620-1627.

TSAI, C. M. \& FrasCH, C. E. (1982). A sensitive silver stain for detecting lipopolysaccharides in polyacrylamide gels. Analytical Biochemistry 119, 115-119.

Tuffrey, M., Falder, P., Gale, J. \& Taylor-Robinson, D. (1986). Salpingitis in mice induced by human strains of Chlamydia trachomatis. British Journal of Experimental Pathology 67, 605-616.

Wu, J. W., Newton, S., Judd, A., Stocker, B. \& Robinson, W. S. (1989). Expression of immunogenic epitopes of hepatitis B surface antigen with hybrid flagellin proteins by a vaccine strain of Salmonella. Proceedings of the National Academy of Sciences of the United States of America 86, 4726-4730.

Yanisch-Perron, C., Vieira, J. \& Messing, J. (1985). Improved M1 3 phage cloning vectors and host strains: nucleotide sequences of the M13mp18 and pUC19 vectors. Gene 33, 103-119.

Zhang, X.-Y., Stewart, S., Joseph, T., Taylor, H. R. \& Caldwell, H. D. (1987). Protective monoclonal antibodies recognise epitopes located on the major outer membrane protein of Chlamydia trachomatis. Journal of Immunology 138, 575-581.

ZhaNG, H., SCHOLl, R., Browse, J. \& Somerville, C. (1988). Double stranded DNA sequencing as a choice for DNA sequencing. Nucleic Acids Research 16, 1220 